\title{
The application of species specific DNA-targeted probes and fluorescently tagged lectin to differentiate several species of Pseudo-nitzschia (Bacillariophyceae) in Chinhae Bay, Korea*
}

\author{
EUN SEOB CHO ${ }^{1}, \mathrm{JONG}_{\mathrm{N}} \mathrm{YU} \mathrm{PARK}^{2}, \mathrm{BONG}_{\mathrm{CHEOL} \mathrm{OH}}{ }^{1}$ and YONG CHUL CHO ${ }^{1}$ \\ ${ }^{1}$ Harmful Algal Research Division, National Fisheries Research and Development Institute, Republic of Korea. \\ E-mail: escho@nfrdi.re.kr \\ ${ }^{2}$ The Institute of Environment Research, Inje University, Pusan, Republic of Korea
}

\begin{abstract}
SUMMARY: We applied molecular methods using a DNA probe and fluorescently tagged lectins to discriminate toxic Pseudo-nitzschia multiseries from the Chinhae Bay for a Korean harmfulalgae monitoring program. From the binding activity of lectins, $P$. multistriata, $P$. subfraudulenta, $P$. pungens, $P$. multiseries and $P$. cuspidata bound ConA, whereas $P$. subpacifica and $P$. delicatissima did not. Ribosomal RNA-targeted oligonucleotide probes (muD1, puD1 and deD1) specifically reacted to $P$. multiseries, $P$. pungens and $P$. delicatissima, respectively, whereas auD1, frD1 and amD1 probes did not bind to $P$. multiseries, $P$. pungens, $P$. cuspidata, $P$. multistriata, $P$. subpacifica, $P$. subfraudulenta and $P$. delicatissima. In particular, fluorescent FITC-conjugated WGA specifically bound to $P$. multiseries but not to $P$. pungens, indicating that this is a desirable method for their rapid and easy discrimination. In addition, we tested a species-specific oligonucleotide DNA probe (muD1) using the whole cell hybridization filter tube system, and the WGA lectin probe to discriminate $P$. multiseries in the field. The oligonucleotide probe and fluorescent WGA bound specifically to $P$. multiseries and these labelled cells were correlated to label cell abundance. These results imply that DNA and lectin probes are apporopriate tools for counting P. multiseries and distinguishing morphologically similar Pseudo-nitzschia species in natural samples, therefore, these methods are especially pertinent since rapid separation and quantitative estimation of cell abundance of $P$. multiseries are now important for a routine harmful algae monitoring program in Korean waters.
\end{abstract}

Key words: Pseudo-nitzschia, differentiation, DNA probes, FITC-conjugated lectins.

\section{INTRODUCTION}

The first Korean record of the blooms dominated by Pseudo-nitzschia spp. was from Masan Bay in 1975 (Yoo and Lee, 1980). Since then, Pseudonitzschia blooms have been annual features in Korean coastal waters (Lee, 1994; Kim et al., 1997; Lee and Baik, 1997). Recently, domoic acid (DA) causing amnesic shellfish poisoning (ASP) was detected

\footnotetext{
*Received June 19, 2000. Accepted March 19, 2001.
}

in Korean shellfish after the implementation of a comprehensive biotoxin monitoring program following a suspected shellfish poisoning event. Recent serious instances of DA contamination in mussels have occurred in many parts of Chinhae Bay, a commercial mussel harvesting site. Both phytoplankton monitoring and shellfish flesh testing programs have led to a database which has helped to link Pseudo-nitzschia species to specific DA occurrences. It is known that DA-contaminated cultured blue mussels caused 107 cases of human poisoning 
and three deaths in Canada (Bates et al., 1989, 1991), but no fish kills or economic impacts were associated with blooms caused by Pseudo-nitzschia in Korean coastal waters (Kim et al., 1997).

Pseudo-nitzschia species that occur in Chinhae Bay include $P$. pungens, $P$. subpacifica, $P$. multistriata and $P$. subfraudulenta (Cho et al., 1999a). However, it is difficult to identify these species under the light microscope due to their morphological similarity (Hasle, 1994). This requires observations using an electron microscope, which are timeconsuming and costly (Scholin et al., 1994). Attempting to solve these problems, some researchers have assessed FITC-conjugated lectins, which exhibit a special characteristic of binding to specific sugars on the cell surface, as a tool for differentiating toxic from non-toxic microalgae (Fritz, 1992; Rhodes et al., 1995, 1998a, b; Fraga et al., 1998). In 1999, we isolated toxic P. multiseries from Chinhae Bay, but when the light microscope was used, it was often misidentified in the field as nontoxic $P$. pungens. In a previous report, lectin probes enabled a risk assessment of biotoxin monitoring events in Korean coastal waters (Cho et al., 1998). Subsequently, we tested the application of fluorescently tagged lectins to discriminate four Pseudonitzschia species and then suggested that this method should be able to identify several species of Pseudo-nitzschia in the field (Cho et al., 1999a). We also showed that this was a promising tool for phytoplankton monitoring in Korean waters.

In this work, we apply a DNA fluorescent probebased whole cell hybridization assay, as well as a fluorescently labelled lectin probe, for rapid detection and enumeration of several species of Pseudonitzschia. We also compared the ability of the DNA probe and the fluorescently labelled lectin probe to discriminate toxic $P$. multiseries from non-toxic $P$. pungens in the context of the Korean biotoxin monitoring program.

\section{MATERIAL AND METHODS}

\section{Isolation}

We isolated 7 species of Pseudo-nitzschia from Chinhae Bay (Table 1). They were collected by picking individual cells with a micropipette under the light microscope or by a serial dilution (Cho et $a l ., 1998)$. After a clonal culture was established, the species were maintained and cultured in $\mathrm{f} / 2+\mathrm{Si}$
TABle 1. - List of Pseudo-nitzschia species used in this study and their toxicity.

\begin{tabular}{ll}
\hline Species & Toxicity \\
\hline & - \\
Pseudo-nitzschia multistriata & - \\
$P$. subpacifica & - \\
$P$. subfraudulenta & - \\
$P$. pungens & + \\
$P$. multiseries & - \\
$P$. cuspidata & - \\
$P$. delicatissima & \\
& \\
aToxicity was analyzed by reversed-phase high-performance liquid \\
chromatography with a fluorescence detector (Ex. 264 nm, Em. 313 \\
nm) supported with UV detection. DA concentration in $P$. multi- \\
series at day 20 was 221.8 ng/mL, 196.4 ng/mL and 25.4 ng/mL in \\
the whole culture, cell-free medium and cell fraction, respectively. \\
The cellular content of DA was estimated at 2.4 pg/cell.
\end{tabular}

(Guillard and Ryther, 1962). These stains were grown in $100 \mathrm{ml}$ polycarbonate flasks at $20^{\circ} \mathrm{C}$, under an intensity of $100 \mu \mathrm{mol} \mathrm{m} \mathrm{m}^{-2} \mathrm{~s}^{-1}$ continuous light provided by cool-white fluorescent lamps.

\section{Morphological analysis}

For the scanning electron microscope (SEM) observations, $5 \mathrm{ml}$ of Pseudo-nitzschia culture were fixed with Lugol's solution. They were acid-cleaned $(1 \mathrm{M} \mathrm{HCL})$ and filtered through a $5 \mu \mathrm{m}$ pore-size polycarbonate membrane filter under no pressure (Lee and Baik, 1997). The washed samples on the filter were air dried, transferred to an aluminum stub, coated with deionized gold, and then examined with an Hitachi S-4200 SEM.

\section{Application of fluorescent by labelled lectins probes}

Fresh solutions of FITC-conjugated lectins (Table 2; Vector Lectin Kit, fluorescein FLK-2100, Vector Laboratories Inc., Burlingame, CA 94010) were prepared as described by Kim et al. (1995). Fluorescein isothiocyanate (FITC)-labelled lectins (Table 2) were added to $10 \mu 1$ aliquots of $10^{3}$ cells on glass slides for $40 \mathrm{~min}$ at room temperature. Slides were coated with a solution of 3-aminopropyltriethoxy-saline (3\%). The treated cells were mounted on siliconised glass slides and examined for binding activity under an epifluorescence microscope: inverted Carl Zeiss MC-80 with an FITC filter set using blue light (excitation, 450-480 nm; emission, $515 \mathrm{~nm}$ ). Binding activity was determined as described by Cho et al. (1998). 
TABLE 2. - Lectin probes used in this study.

\begin{tabular}{lll}
\hline Lectin & Source & Specificity \\
\hline ConA & Canavalia ensiformis & Methyl $\alpha$-D-mannopyranoside; D-mannose; D-glucose \\
RCA & Ricinus communis & $\beta$-D-galactose \\
DBA & Dolchis biflorus & N-acetyl-D-galactosamine \\
PNA & Arachis hypogaea & $\alpha$-lactose; D-galactose \\
SBA & Glycine maxima & N-acetyl-D-galactosamine; D-galactose; methyl $\alpha$-D-galactopyranoside \\
UEA & Ulex europaeus & L-fucose \\
WGA & Triticum vulgaris & N-triacetylchitotriose; N-diacetylchitobiose; sialic acid \\
\end{tabular}

\section{Whole-cell probing of Pseudo-nitzschia species}

At least 2,000 cells were captured on $25 \mathrm{~mm}, 0.8$ $\mu \mathrm{m}$ pore-size Nuclepore Track-Etch membrane filters placed in custom made filter tubes. We filtered $10 \mathrm{ml}$ of whole water per tube and used the least amount of vacuum possible $(>100 \mathrm{mmHg})$. Once the cells were captured on the filter, the following was sequentially added to each tube: $5 \mathrm{ml}$ of freshly prepared saline EtOH fixative, $3 \mathrm{ml} 25 \mathrm{X}$ SET $(3.75 \mathrm{M}$ $\mathrm{NaCl}, 25 \mathrm{mM}$ EDTA, $0.5 \mathrm{M}$ Tris pH 7.8), $25 \mathrm{ml}$

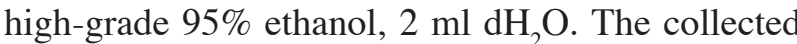
cells were allowed to fix at room temperature for 1 h. Afterward, samples were filtered and rinsed briefly with $1 \mathrm{ml}$ hybridization buffer $[(189.0 \mathrm{ml}$ $\mathrm{dH}_{2} \mathrm{O}, 48.0 \mathrm{ml} 25 \mathrm{X}$ SET, $2.4 \mathrm{ml}$ 10\% IGEPALCA630 (Sigma)], $0.6 \mathrm{ml}$ Polyadenylic acid (Sigma). Cells were filtered and then $500 \mu \mathrm{l}$ of hybridization buffer were added to each tube to resuspend cells before adding $12 \mu \mathrm{l}$ of the appropriate probes, cap tubes then placed manifold into a waterbath or dry incubator at $45^{\circ} \mathrm{C}$ for $1 \mathrm{hr}$ to hybridise. After hybridisation, filter and then risen briefly with $1 \mathrm{ml}$ of 5 X SET (dilution of $25 \times$ SET) to remove excess unbound probe for 10 minutes. After filtration, place membranes onto glass slides, add $20 \mu \mathrm{l}$ Slow Fade Light (Molecular probes) to each membrane, mount cover slip, then viewed under a Nikon Optiphot microscope with a FITC optical filter set (excitation 450-490 nm; emission $529 \mathrm{~nm}$ ). This study used 8 kinds of probes (Scholin et al., 1996); muD1 (specific probe for $P$. multiseries), puD1 (specific probe for $P$. pungens), auD1 (specific probe for $P$. australis), frD1 (specific probe for $P$. fraudulenta), amD1 (specific probe for P. americana), deD1 (specific probe for $P$. delicatissima), uniC (positive control for all eukaryotes), uniR (negative control to test for non-specific retention of probe) and no probe (negative control to compare uniR for autofluorescence versus non-specific retention of probe). To estimate cell density for discriminate $P$. multiseries, nine natural samples in this study were collected from different Chinhae Bay (Chinhae, Wuchong, Masan, Hapo, Nampo, Myongdong, Lidong, Dukdong and Jindong) and immediately returned to the laboratory and concentrated with a mesh size of 20 $\mu \mathrm{m}$. To identify and enumerate toxic P. multiseries, we counted cells labelled with the fluorescent WGA lectin and the muD1 DNA probe using an epifluorescent microscope as above.

\section{RESULTS}

\section{Morphological characteristics of Pseudo-nitzschia species by SEM}

During this study, the genus of Pseudo-nitzschia occurred in Chinhae Bay was P. pungens, $P$. multiseries, $P$. cuspidata, $P$. multistriata, $P$. subpacifica, $P$. subfraudulenta and P. delicatissima (Table 3). Pseudo-nitzschia pungens showed 9-12 fibulae in $10 \mu \mathrm{m}$, two rows of poroids, and three to four poroids in 1 $\mu \mathrm{m}$ (Fig. 1a). The morphologically similar P. multi-

TABLE 3. - Morphometric data of Pseudo-nitzschia species occurred in Chinhae Bay.

\begin{tabular}{|c|c|c|c|c|c|}
\hline Species & Apical axis $(\mu \mathrm{m})$ & Central nodule & Fibulae in $10 \mu \mathrm{m}$ & Row of poroids & Poroids in $1 \mu \mathrm{m}$ \\
\hline P. pungens & $85-130$ & - & $9-12$ & 2 & $3-4$ \\
\hline P. multiseries & $70-100$ & - & $13-14$ & $3-4$ & $4-6$ \\
\hline P. cuspidata & $60-65$ & + & $15-16$ & 1 & $5-6$ \\
\hline P. multistriata & $60-65$ & - & $22-23$ & 2 & $10-11$ \\
\hline P. subpacifica & $35-45$ & + & $13-17$ & 2 & $6-7$ \\
\hline P. subfraudulenta & $70-85$ & + & $14-16$ & 2 & $5-6$ \\
\hline P. delicatissima & $30-45$ & + & $21-22$ & 2 & $10-12$ \\
\hline
\end{tabular}




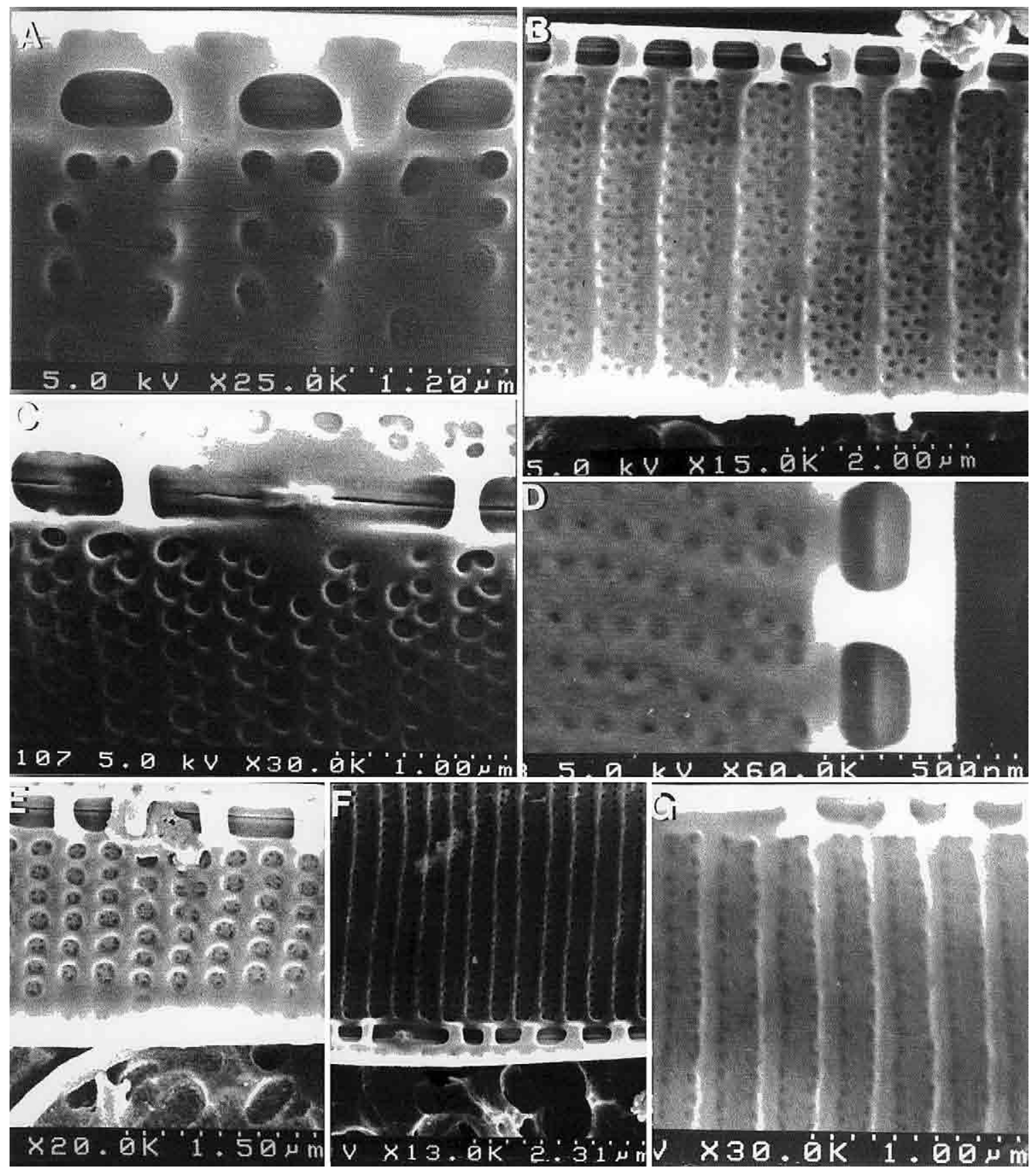

FIG. 1. The Pseudo-nitzschia species observed in Chinhae Bay: A: P. pungens, B: P. multiseriese, C: P. cuspidata, D: P. multistriata, E: P. subpacifica, F: P. subfraudulenta, G: P. delicatissima. The scale bar is represented on the bottom of each Figure.

series had 13-14 fibulae in $10 \mu \mathrm{m}$, three to four rows of poroids, and four to six poroids in $1 \mu \mathrm{m}$ (Fig. 1b). However, both strains showed a similar characteristics of cell length $(70-130 \mu \mathrm{m})$ and the absence of central nodule. Pseudo-nitzschia cuspidata and $P$. multistriata had a similar cell length $(60-65 \mu \mathrm{m})$, but the number of fibulae in $10 \mu \mathrm{m}$, the number of rows of poroids, and poroids in $1 \mu \mathrm{m}$ were different; 15 16, 1 and 5-6 in P. cuspidata, and 22-23, 2 and 10-11 in $P$. multistriata, respectively (Fig. 1c, d). Central
TABLE 4. - Binding of Pseudo-nitzschia species to FITC-labelled lectins.

\section{Strains}

ConA PNA SBA UEA WGA DBA RCA

Pseudo-nitzschia multistriata + P. subpacifica $P$. subfraudulenta $P$. pungens $P$. multiseries $P$. delicatissima

P. cuspidata

$\begin{array}{llllll}- & - & - & - & - & - \\ - & - & - & - & - & - \\ - & - & - & - & - & - \\ - & - & - & - & - & + \\ - & - & - & + & - & + \\ - & - & - & - & - & - \\ - & - & - & - & - & -\end{array}$


TABLE 5. - Response of different Pseudo-nitzschia spp. to DNA probes. The symbols '+' and '-' represent binding and non-binding to DNA probes tested, respectively.

\begin{tabular}{|c|c|c|c|c|c|c|c|c|c|}
\hline Species & $\mathrm{muD}^{1}$ & puD1 ${ }^{2}$ & $\mathrm{auD} 1^{3}$ & $\mathrm{frD}^{4}$ & $\mathrm{amD} 1^{5}$ & $\operatorname{deD} 1^{6}$ & uniC $^{7}$ & uniR $^{8}$ & no probe ${ }^{9}$ \\
\hline P. pungens & - & + & - & - & - & - & + & - & - \\
\hline P. multiseries & + & - & - & - & - & - & + & - & - \\
\hline P. cuspidata & - & - & - & - & - & - & + & - & - \\
\hline P. multistriata & - & - & - & - & - & - & + & - & - \\
\hline P. subpacifica & - & - & - & - & - & - & + & - & - \\
\hline P. subfraudulenta & - & - & - & - & - & - & + & - & - \\
\hline$P$. delicatissima & - & - & - & - & - & + & + & - & - \\
\hline
\end{tabular}

${ }_{1}^{1}$ specific probe for P. multiseries, ${ }^{2}$ specific probe for P. pungens, ${ }^{3}$ specific probe for P. australis, ${ }^{4}$ specific probe for P. fraudulenta, ${ }^{5}$ specific probe for $P$. americana, ${ }^{6}$ specific probe for $P$. delicatissima, ${ }^{7}$ positive control for all eukaryotes, ${ }^{8}$ negative control to test for non-specific retention of probe, ${ }^{9}$ negative control to compare against uniR for autofluorescence versus non-specific retention of probe

nodule was shown in $P$. cuspidata, whereas was not in P. multistriata. In P. subpacifica (cell length, 35$45 \mu \mathrm{m})$ there were 13-17 fibulae in $10 \mu \mathrm{m}$, two rows of poroids, and six to seven poroids in $1 \mu \mathrm{m}$ (Fig. 1e). Pseudo-nitzschia subfraudulenta (cell length, 70-85 $\mu \mathrm{m}$ ) had 14-16 fibulae in $10 \mu \mathrm{m}$, two rows of poroids, and 5-6 poroids in $1 \mu \mathrm{m}$ (Fig. 1f). A smaller species, $P$. delicatissima was easily differentiated from the others by its smaller cell size $(30-45 \mu \mathrm{m})$; 21-22 fibulae in $10 \mu \mathrm{m}$, two rows of poroids and 1012 poroids in $1 \mu \mathrm{m}$ (Fig. $1 \mathrm{~g}$ ). Three species of $P$. subpacifica, $P$. subfraudulenta and $P$. delicatissima had central nodule.

\section{Lectin binding to Pseudo-nitzschia species}

The lectin response of the Pseudo-nitzschia species is given in Table 4. Pseudo-nitzschia multistriata, $P$. subfraudulenta, $P$. pungens, $P$. multiseries and $P$. cuspidata all bound with ConA, whereas $P$. subpacifica and $P$. delicatissima showed no binding with any of the different lectins in this study. The RCA probe bound with $P$. pungens and $P$. multiseries, which could also not be differentiated from each other under the light micscope because of their morphological similarity. However, WGA specifically conjugated to $P$. multiseries, which showed a fine fluorescent outline of the cell, whilst none bound to P. pungens.

\section{DNA probe in the cultured Pseudo-nitzschia species}

The $P$. multiseries probe (muD1), P. pungens probe (puD1) and $P$. delicatissima probe (deD1) were positive, whereas $P$. cuspidata, $P$. multistriata, $P$. subpacifica and $P$. subfraudulenta were not shown in 3 kinds of probes (Table 5). However, the auD1,
frD1 and amD1 DNA probes did not bind to P. multiseries, $P$. pungens, $P$. cuspidata, $P$. multistriata, $P$. subpacifica, $P$. subfraudulenta and $P$. delicatissima.

\section{muD1 probe and WGA lectin assay in field samples}

Treatment of $P$. multiseries in nature with lectin WGA showed a green fluorescence signal on the cell surface against a background of other plankton and organic matter (Fig. 2a). In addition, the whole
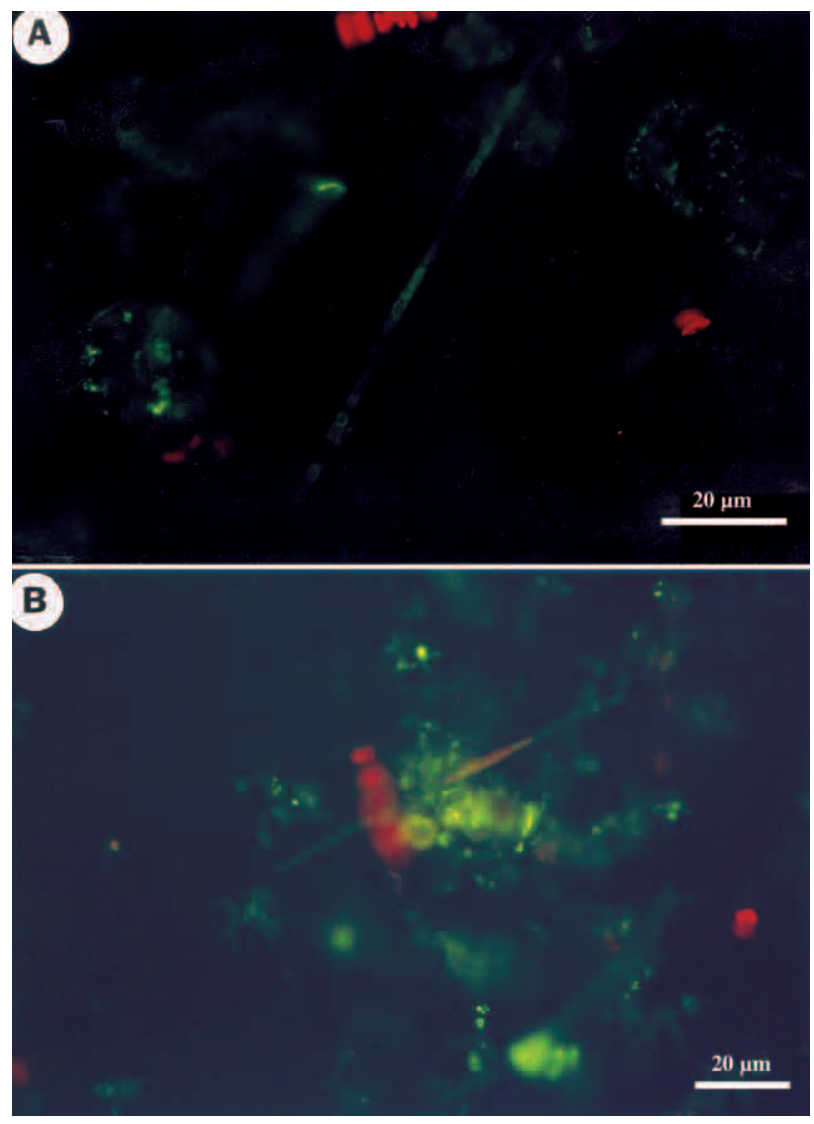

FIG. 2. Epifluorescence micrographs of toxic P. multiseries in the field. A: FITC-conjugated WGA lectin. B: Cells hybridized with species-specific probe muD1. 


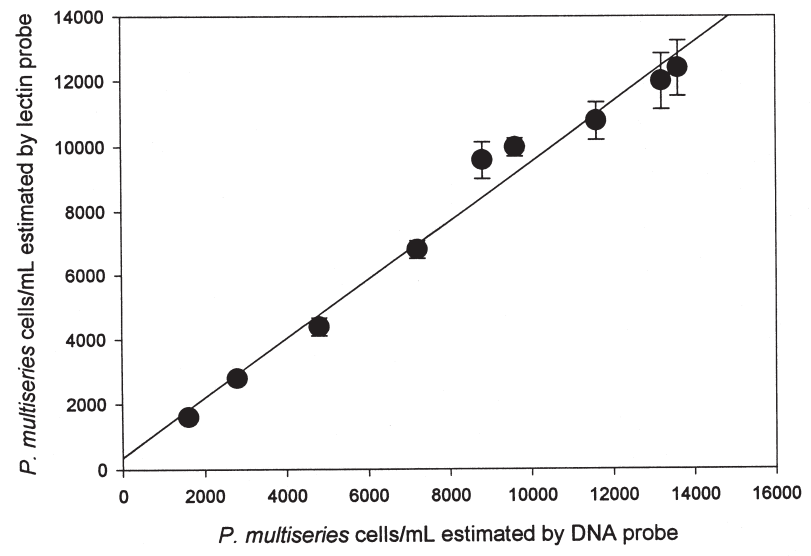

FIG. 3. Comparison of cell densities estimated by DNA probe and WGA lectin collected from the field.

cell muD1 probe successfully labelled only $P$. multiseries (Fig. 2b), and WGA lectin assay results were well correlated $\left(r^{2}=0.97, n=9\right.$, Fig. 3$)$.

\section{DISCUSSION}

Five species of Pseudo-nitzschia (P. cuspidata, $P$. multistriata, $P$. subpacifica, $P$. subfraudulenta and $P$. delicatissima) are for the first time recorded in Korea. Although P. cuspidata had similarities to $P$. multistriata based on morphological features, the number of fibulae in $10 \mu \mathrm{m}$ and poroids in $1 \mu \mathrm{m}$ played on important role in differentiating P. cuspidata from P. multistriata (Table 3). However, discriminating $P$. cuspidata from P. multistriata depends on whether or not a central nodule is present. Pseudo-nitzschia subpacifica was morphologically similar to $P$. heimii as described by Hasle (1996), but P. subpacifica based on morphological characteristics of cell length, cell width, cell formation, etc, was shown in this study. However, the number of poroids in $1 \mu \mathrm{m}$ are similar to P. heimii.

Lectins are differentiated by their specific carbohydrate affinity for glucose/mannose, galactose/Nacetyl-D-galactosamine, $\mathrm{N}$-acetyl-glucosamine, fucose or sialic acids (Slifkin and Doyle, 1990). Because of their ability to bind with different carbohydrates at the cell surface, fluorescently tagged lectins have been used as probes for species identification (Costas and Lopez-Rodas, 1994; Rhodes et al., 1995; Cho et al., 1998; Fraga et al., 1998). In particular, when it is difficult to distinguish species under the light microscope, each could be easily differentiated according to its individual lectin binding affinity (Rhodes et al., 1995). Following this, several researchers have suggested that fluorescently tagged lectin probes are a potential tool for species identification in harmful algae monitoring programs (Costas et al., 1993, 1994, 1995; Rhodes et al., 1995). For example, Cho et al. (1998) reported that ECA, HPA and WGA could differentiate the harmful algal Cohlodinium polykrikoides from the nontoxic Gyrodinium impudicum, whose morphologies are so similar that it was difficult to identify them under the light microscope.

From Table 3, FITC-conjugated lectin probes allowed some differentiation of the diatoms P. multistriata, $P$. subpacifica, $P$. subfraudulenta, P. pungens, P. multiseries, $P$. delicatissima and P. cuspidata in this study. Pseudo-nitzschia multistriata, $P$. subfraudulenta, $P$. pungens, $P$. multiseries and $P$. cuspidata bound ConA, with a fine fluorescent outline of the cell being observed, whereas $P$. subpacifica and $P$. delicatissima did not bind ConA. ConA is suitable for differentiating $P$. subpacifica and $P$. delicatissima from the other tested Pseudo-nitzschia spp., but $P$. multistriata, $P$. subfraudulenta and $P$. cuspidata were not differentiated by fluorescent lectins. Meanwhile, P. pungens and P. multiseries both showed binding activity with ConA and RCA, suggesting that RCA could be used to easily discriminate $P$. pungens and $P$. multiseries from the other tested Pseudo-nitzschia species.

Pseudo-nitzschia multistriata, P. subfraudulenta, $P$. pungens, $P$. multiseries and $P$. cuspidata therefore have glucose and mannose like sugar moieties at the cell surface (Table 4), but are lacking glucosamine and galactosamine, compared to some other Korean coastal red tide microalgae (Cho et al., 1998). Pseudo-nitzschia multiseries and P. pungens have similar morphological features, as is the case with $C$. polykrikoides and G. impudicum, but different nucleic acid sequences (Douglas et al., 1994; Scholin et al., 1994; Manhart et al., 1995; Cho et al., 2001). However, WGA might play an important role in differentiating Korean P. multiseries from P. pungens (Table 3). This result agrees with those of Fraga et al. (1998) and Rhodes et al. (1998b) .Meanwhile, Rhodes (1998a) has reported that SBA lectin also could play a taxonomic tool as species identification of $P$. multiseries and $P$. pungense. However, $P$. multiseries and $P$. pungens showed no binding affinity with SBA in this study, it is likely that the production of surface sugars by Pseudo-nitzschia varies depending on geographical separation and environmental conditions. 
Miller and Scholin (1996) suggested that the species-specific DNA probe method is a rapid, simple and cost-effective technique for discriminating among cultured Pseudo-nitzschia species. Additionally, Scholin et al. (1996) have reported a sandwich hybridization method for detecting Pseudo-nitzschia species in plankton samples, which was simpler than whole cell hybridization and was able to be automated. Scholin et al. (1997) suggested that both whole cell and sandwich hybridization were useful methods for detecting targeted species of Pseudonitzschia in culture and natural samples. In this study, $P$. multiseries treated with the DNA probe was readily identified and enumerated in field samples, although it had a weaker fluorescence signal intensity than cells treated with WGA lectins (Fig. 2). Therefore, detection and enumeration of toxic $P$. multiseries using this DNA fluorescent probe-based whole cell hybridization assay and the WGA lectin binding assay will be carried out in the near future for the Korean harmful algae monitoring program.

\section{ACKNOWLEDGEMENTS}

The authors thank Dr. C.A. Scholin, Monterey Bay Aquarium Research Institute, USA, for valuable advice and relevant papers. We thank to H.J. Hur, The Institute of Environmental Research, Inje University, Kimhae, Korea, and D.W. Kang, Harmful Algal Research Division, National Fisheries Research and Development Institute, Pusan, Korea, for providing laboratory cultures. We thank J.P. Kim, Korea Basic Science Institute Pusan Branch for SEM and the Bioneer company, for the fluorescein at 5' end. We are grateful to Dr. G. Kazwya, National Research Institute of Far Seas Fisheries, Shimizu-shi, Japan for his suggestion and correction of English. An anonymous reviewer made valuable comments on the manuscript. This work was supported by a grant-in-aid from the Maritime Affairs and Fisheries Ministry of Korea.

\section{REFERENCES}

Bates, S.S., C.J. Bird, A.S.W. de Freitas, R. Foxall, M. Gilgan, L.A. Hanic, G.R. Johnson, A.W. McCulloch, P. Odense, R. Pocklington, M.A. Quilliam, P.G. Sim, J.C. Smith, D.V. Subba Rao, E.C.D. Todd, J.A. Walter and J.L.C. Wright. - 1989. Pennate diatom Nitzschia pungens as the primary source of domoic acid, a toxin in shellfish from eastern Prince Edward Island, Canada. Can. J. Fish. Aquat. Sci., 46: 1203-1215.

Bates, S.S., A.S.W. de Freitas, J.E. Milley, R. Pocklington, M.A Quilliam, J.C. Smith and J. Worms. - 1991. Controls on domoic acid production by the diatom Nitzschia pungens $\mathrm{f}$. multiseries in culture: nutrients and irradiance. Can. J. Fish. Aquat. Sci., 48: 1136-1144.

Cho, E.S., G.M. Seo, S.G. Lee, H.G. Kim, S.J. Lee, L.L. Rhodes and Y.K. Hong. - 1998. Application of FITC-conjugated lectin probes for the recognition and differentiation of some Korean coastal red tide microalgae. J. Fish. Sci. Tech., 1: 250-254.

Cho, E.S., G.Y. Kim, B.D. Choi, L.L. Rhodes, T.J. Kim, G.H. Kim and J.D. Lee. - 2001. The comparative study of harmful dinoflagellates Cochlodinium polykrikoides and Gyrodinium impudicum using transmission electron microscope (TEM), fatty acid composition, carotenoid content, DNA quantification and gene sequences. Bot. Mar., 44: 57-66.

Cho, E.S., J.G. Park, H.G. Kim, C.H. Kim, L.L. Rhodes and C.S. Chung. - 1999a. The rapid differentiation of toxic Alexandrium and Pseudo-nitzschia species using fluorescent lectin probes. $J$. Oceanol. Soc. Korea, 34: 167-171.

Costas, E., A. Gonzalez-Chavarri, A. Aguiera, S. Gonzalez-Gil and V. Lopez-Rodas. - 1993. Use of lectins to recognize and differentiate unicellular algae. Bot. Mar., 36: 1-4.

Costas, E., R. Zardoya, J. Bautista, A. Garrido, C. Rojo and V. Lopez-Rodas. - 1995. Morphospecies vs. Genospecies in toxic marine dinoflagellates: An analysis of Gymnodinium catenatum/Gyrodinium impudicum and Alexandrium minutum/A. lusitanicum using antibodies, lectins, and gene sequences. J. Phycol., 3: 801-807.

Costas, E. and V. Lopez-Rodas. - 1994. Identification of marine dinoflagellates using fluorescent lectins. J. Phycol., 30: 987-990.

Douglas, D.J., D. Landry and S.E. Douglas. - 1994. Genetic relatedness of toxic and non-toxic isolates of the marine pennate diatom Pseudonitzschia (Bacillariophyceae): phylogenetic analysis of 18S rRNA sequences. Natural Toxins, 2: 166-174.

Fraga, S., M.J. Alvarez, A. Miguez, M.L. Fernandez, E. Costas and V. Lopez-Rodas. - 1998. Pseudo-nitzschia species isolated from Galician waters: toxicity, DNA content and lectin binding assay. In: B. Reguera, J. Blanco, M.L. Fernadez and T. Wyatt (eds.), Harmful Algae, Xunta de Galicia and IOCof UNESCO, pp. 270-273.

Fritz, L. - 1992. The use of cellular probes in studying marine phytoplankton. Korean J. Phycol., 7: 319-324.

Guillard, R.R.L. and J.H. Ryther. - 1962. Studies of marine planktonic diatoms 1. Cycotella nana HUSTEDT, and Detonula confervacea (Cleve) Gran. Can. J. Microbiol., 8: 229-239.

Hasle, G.R. - 1994. Pseudo-nitzschia as a genus distinct from Nitzschia (Bacillariophyceae). J. Phycol., 30: 1036-1039.

Kim, G.H., I.K. Lee and L. Fritz. - 1995. The wound-healing responses of Antithamnion nipponicum and Griffithsia pacifica (Ceramiales, Rhodophyta) monitored by lectins. Phycol. Res., 43: 161-166.

Kim, H.G., S.G. Lee, K.H. An, S.H. Youn, P.Y. Lee, C.K. Lee, E.S. Cho, J.B. Kim, H.G. Choi and P.J. Kim. - 1997. Recent Red Tides in Korean Coastal Waters. Kuduk Publsihing, Pusan, 292pp. (in Korean)

Lee, J.H. - 1994. Neurotoxin-producing diatom, Pseudonitzschia pugens Grunow f. multieries Hasle, off the coastal waters of southern Korea. I. Morphological features. Korean J. Phycol., 9: $125-134$.

Lee, J.H. and J.H. Baik. - 1997. Neurotoxin-producing Pseudonitzschia multiseries (Hasle) Hasle, in the coastal waters of Southern Korea. II. Production of domoic acid. Algae 12: 31-38.

Manhart, J.R., G.A. Fryxell, C. Villac and L.Y. Segura. - 1995. Pseudo-nitzschia pungens and P. multieries (Bacillariophyceae): nuclear ribosomal DNAs and species differences. $J$. Phycol., 31: 421-427.

Miller, P.E. and C.A. Scholin. - 1996. Identification of cultured Pseudo-nitzschia (Bacillariophyceae) using species-specific LSU rRNA-targeted fluorescent probes. J. Phycol., 32: 646655.

Miller, P.E. and C.A. Scholin. - 1998. Identification and enumeration of cultured and wild Pseudo-nitzschia (Bacillariophyceae) using species-specific LSU rRNA-targeted fluorescent probes and filter-based whole cell hybridization. J. Phycol. 34: 371-382.

Rhodes, L.L. - 1998a. Identification of potentially toxic Pseudonitzschia (Bacillariophyceae) in New Zealand coastal waters, using lectins. New Zealand J. Mar. Fresh. Res., 32: 537-544.

Rhodes, L.L., C. Scholin, I. Garthwaite, A.J. Haywood and A. Thomas. - 1998b. Domoic acid producing Pseudo-nitzschia species deduced by whole cell probe-based and immunochemi- 
cal assays. In: B. Reguera, J. Blanco, M.L. Fernadez and T. Wyatt (eds.): Harmful Algae, Xunta de Galicia and IOC of UNESCO, pp. 274-277.

Rhodes, L.L., A.J. Haywood and D.W. Fountain. - 1995. FITCconjugated lectins as a tool for differentiating between toxic and non-toxic marine dinoflagellates. New Zealand J. Mar. Fresh. Res., 2: 359-365.

Scholin, C., P. Miller, K. Buck and F. Chavez. - 1997. Detection and quantification of Pseudo-nitzschia australis in cultured and natural populations using LSU rRNA-targeted probes. Limnol. Oceagnogr., 42: 1265-1272.

Scholin, C.A., K.R. Buck, T. Britschgi, G. Cangelosi and E.P. Chavez. - 1996. Identification of Pseudo-nitzschia austalis
(Bacillariophyceae) using rRNA-targeted probes in whole cell and sandwich hybrization formats. Phycologia, 35: 190-197.

Scholin, C.A., M.C. Villac, K.R. Buck, J.M. Krupp, D.A. Powers, G.A. Fryxell and F.P. Chavez. - 1994. Ribosomal DNA sequences discriminate among toxic and non-toxic Pseudonitzschia species. Natural Toxins, 2: 152-165.

Slifkin, M. and R.J. Doyle. - 1990. Lectins and their application to clinical microbiology. Clin. Microbiolo. Rev., 3: 197-218.

Yoo, K.I. and J.H. Lee. - 1980. Envrionmental studies of the Jinhae Bay. 3. Ecological succession of phytoplankton populations. 1974-1980. J. Oceanol. Soc. Korea, 15: 100-107.

Scient. ed.: C. Pedrós-Alió 